Bekteshi, E., \& Xhaferi, B. (2020). Learning about Sustainable Development Goals through English Language Teaching.

\title{
Learning about Sustainable Development Goals through English Language Teaching
}

Edita Bekteshi*

University of Mitrovica "Isa Boletini"

Brikena Xhaferi

South East European University

*Corresponding Author: edita.bekteshi@umib.net

Received : 2020-05-18

Rev. Req. : 2020-05-30

Accepted : 2020-07-18

or

DOI: $10.46303 /$ ressat.05.03.4

How to cite this paper: Bekteshi, E., \& Xhaferi, B. (2020). Learning about sustainable development goals through English language teaching. Research in Social Sciences and Technology, 5 (3), 78-94. https://doi.org/10.46303/ressat.05.03.4

This is an Open Access article distributed under the terms of the Creative Commons Attribution 4.0 International license (https://creativecommons.org/licenses/by/4.0/)

\begin{abstract}
The purpose of this paper is to introduce the concept of Sustainable Development (SD) and its goals to the students of the Faculty of Education, future teachers, in order to become skilled and knowledgeable and then introduce these Sustainable Development Goals (SDGs) to their students. As such, this study tries to link the concept of English Language Learning (ELL), English Language Teaching (ELT), and the SDGs as a type of all-inclusiveness within the "3 Ps": Planet, People, and Profit. The instrument used for the purpose of this study was an online questionnaire sent to the students of the Faculty of Education in Kosovo. The total number of participants was 89 . The students' responses revealed that 60 percent of the future teachers are aware of the SD concept; however, the results indicate that not all "3 Ps" are hit upon by the future teachers. Based on the results, the most common areas of interest and societal needs of learning about SDGs are related to education, gender equality, good health and wellbeing, alleviation of poverty, and decent work and economics. These same goals are also hit upon in ELT classes. The study concludes that Kosovo's future teachers are more concerned about issues related to social issues - "P-People" — followed by goals related to "P-Profit," while goals related to "P-Planet," the environment, are left behind. Future teachers' knowledge about SDGs is vital, for there is a significant direct impact of learning about specific SDGs in higher education institutions, and the application of SDG topics in English language classes can infuse the SD concepts.
\end{abstract}

Keywords: Sustainable Development, students, education, English 
Bekteshi, E., \& Xhaferi, B. (2020). Learning about Sustainable Development Goals through English Language Teaching.

\section{Introduction}

Sustainable Development (SD) has become the milestone of the $21^{\text {st }}$ century in which all world stakeholders are trying to fulfill the needs of society. More precisely, the 2030 Agenda for SD and its 17 Sustainable Development Goals (SDGs), adopted by the United Nations in September 2015 , provide the understanding of $21^{\text {st }}$-century global concerns, specifically:

GOAL 1: No Poverty

GOAL 2: Zero Hunger

GOAL 3: Good Health and Well-being

GOAL 4: Quality Education

GOAL 5: Gender Equality

GOAL 6: Clean Water and Sanitation

GOAL 7: Affordable and Clean Energy

GOAL 8: Decent Work and Economic Growth

GOAL 9: Industry, Innovation and Infrastructure

GOAL 10: Reduced Inequality

GOAL 11: Sustainable Cities and Communities

GOAL 12: Responsible Consumption and Production

GOAL 13: Climate Action

GOAL 14: Life Below Water

GOAL 15: Life on Land

GOAL 16: Peace and Justice Strong Institutions

GOAL 17: Partnerships to Achieve the Goal

SD deals with themes that "determine the daily lives of people of all ages living in different living conditions" (Rieckmann, 2018, p. 62), which are better represented as the "3 Ps": People, Planet, and Profit (Gil-Doménech \& Berbegal-Mirabent, 2018). Additionally, the United Nations Department of Economic and Social Affairs (2018) discusses more detailed "Ps," i.e., the "5 Ps": People, Planet, Prosperity, Peace, and Partnership. The SD aim is to train the new generation to make a difference in themselves and about global issues. In fact, based on the global evolution, SD requires education and training of people themselves, so it is a continuous process. If the new generation is given an intercultural perspective, then this generation will be dedicated to the " 3 Ps" because they will be confident and able to follow the rapid changes around the world (Leicht, Heiss, \& Byun, 2018). We may relate to the claim of Pope and Patterson (2012) that "citizenship and environmental education are broadly tasked with helping students develop the knowledge, skills, and attitudes needed to shepherd the body politic and natural world, respectively, into the future" (p. 1). 
Bekteshi, E., \& Xhaferi, B. (2020). Learning about Sustainable Development Goals through English Language Teaching.

Achieving greater sustainability means "fundamentally addressing the way we see ourselves in connection to others, and the world around us" (Bowden, 2010, p. 16). Let us examine the reasons why should we teach the SDGs: Students/future teachers need to learn about the world, must be active participants in the world they live in, should learn empathy and compassion, and must be inspired to take action (Bakalar, 2018; Weeks, 2018). Students need a higher level of knowledge, which can be achieved by the interaction about a specific context (Richards \& Rodgers, 1986). This higher level of knowledge shares new experiences, leading to "real learning," which is important for the scholars of the $21^{\text {st }}$ century as it enables them to enhance their competency, tenacity, and inquisitiveness (Tarman \& Dev, 2018).

Since SD deals with experiences that facilitate global changes toward more social development, i.e., sustainable societies (Bowden, 2010), there is also a need for education that "will address the growing environmental challenges facing the planet" (Leicht, Heiss, \& Byun, 2018, p. 7). Education for Sustainable Development (ESD) is a concept that will fulfill society's need to respond to these challenges, as it goes far beyond environmental education (Beka \& Ciani, 2015) and is considered the most important tool to reshape worldviews (Kioupi \& Voulvoulis, 2019). As such, ESD "encourages changes in knowledge, skills, values and attitudes to enable a more sustainable society for all" (Leicht, Heiss, \& Byun, 2018, p. 6).

Given that English is the language of the $21^{\text {st }}$ century, and there are many connections between English and Education for Sustainability, English can be used to challenge this century's worldviews (Bowden, 2010; Zygmunt, 2016). At its core, the English language is multi-functional and plays a constitutive role in human life (Bowden, 2010; Inceli, 2015; Kioupi \& Voulvoulis, 2019; Richards \& Rodgers, 1986; Zygmunt, 2016). Its significant role effects the development of the society, which is based on different skill perceptions, critical thinking, creativity, and expression. Goal 4 of the SDGs, Quality Education, "is a means for achieving all the Goals, while maintaining sustainability as the target" (Kioupi \& Voulvoulis, 2019, p. 1). As such, the promotion of language education should be given reasonable support (Zygmunt, 2016), as it would strengthen the impact of ELT on sustainability (Bowden, 2010). Provided that SD topics encompass important worldwide issues, the question "How and why are English learning and inculcating SDGs linked?" also responds to Bowden (2010), who claims that English learning through SD topics is paramount. This connection makes a good case for learning SD via ELT (Balčiūnaitienè \& Teresevičienè, 2018; Bowden, 2010; Parker, 2019; Zygmunt, 2016). Additionally, in order to create impact sustainability through ELT, "ELT teachers and learners need to engage with the wider society in exploring, developing and manifesting sustainability values, enabling them to act as agents for change" (Bowden, 2010, p. 21). Precisely, "differentiated knowledge about different topics from different areas should also be available 
Bekteshi, E., \& Xhaferi, B. (2020). Learning about Sustainable Development Goals through English Language Teaching.

to learners to allow them to analyze different information from alternative perspectives" (Rieckmann, 2018, p. 69). Therefore, it is the teachers' and students' roles that define the type of interaction and effective teaching strategies (Richards \& Rodgers, 1986) about SD.

Effective teaching strategies based on ESD include a variety of issues and practices. These practices are intertwined with various categories in which the " $4 \mathrm{Cs}$ " are presented: Collaboration, Communication, Critical Thinking, and Creativity (Bekteshi, 2017). Interdisciplinary collaborative learning (Kioupi \& Voulvoulis, 2019) encourages discussion about SD or presentation of SD in various ways. This new academic teaching provides modern GloCal (global and local teaching) teaching (Bekteshi, 2017) by incorporating different SDG topics, updated information, resources, and technologies.

It is the teacher who pulls the trigger on ESD, pointed out by the UNESCO (2017) Learning Goals for Teachers to Promote SD (11 Goals). These goals focus upon the importance of the teacher in SD promotion: "Know about sustainable development and the related topics and challenges" and "Understand the discourse on, and the practice of ESD in the local, national and global context" (UNESCO, 2017, p. 52). Other goals deal with cultural diversity, gender equality, social justice, environmental protection, and personal development as integral elements of ESD and how they can be made part of educational processes (UNESCO, 2017).

\section{Purpose of the Study: Language Development via SDG Learning}

Being willing and able to adapt in the $21^{\text {st }}$ century is vital. As such, there is an urgent need to change and transform the system of education into more effective education. Instructional practices, attitudes, and motivation of teachers are needed to bring this transformation (Qablan, 2018; Rieckmann, 2018; Vural, 2019). Accordingly, this transformation means the promotion of SD and the promotion of ESD as a leading goal of the 17 SDGs.

Considering that Kosovo is a new country, having declared independence in 2008, it has made progress in developing legislation for sustainable development. Although SD is a new concept to Kosovar people, it fails to be implemented (Beka \& Ciani, 2015). Initially, SD at higher education institutions in Kosovo, as in other countries, was presented with topics in the field of agriculture or environment (Beka \& Ciani, 2015; Zygmunt, 2016), but SD is not just about these fields; it is about the perception of the "3 Ps": People, Planet, and Profit (Gil-Doménech \& Berbegal-Mirabent, 2018), and ESD needs to be offered, especially to HEIs. As such, the present study addresses SDG issues and discusses the effect of ELT on SDGs and HEl development, specifically at the Faculty of Education. 
Bekteshi, E., \& Xhaferi, B. (2020). Learning about Sustainable Development Goals through English Language Teaching.

There is a strong reason to present the SDGs, particularly at the Faculty of Education. Since students of this faculty will be future teachers, they should be the first to have some knowledge about SD and introduce SD to the learners (Beka \& Ciani, 2015). Adding the fact that "human contacts on the macro scale are only possible via language" (Zygmunt, 2016, p. 117) and that English is the global language (Bowden, 2010; Zygmunt, 2016), then it is important to see the parallel relation between ESD and ELT. As such, "it is challenging for pedagogues to believe that English as a Foreign Language (EFL) will improve students' SD competence" (Balčiūnaitienè \& Teresevičienè, 2018, p. 45). Naturally, the prominent position of English learning at HEls may be used to impact SD, followed by learning about various topics regarding SDGs. In addition, topics that promote SD meet the long-term needs of the students, and valuing SDGs' diversity can help value the topics to be promoted in EL classes.

\section{Research Questions}

This study tries to answer the following questions:

- To what extent are the students in tertiary education (at a public HEI in Kosovo) aware of SD and its goals?

- Which SDGs do students/future teachers consider to be important goals that they need to know?

- Which goals do the students consider as the eminent goals in the country? Which goals do the students consider less applicable in their country?

- To what extent are topics presented in EL classes valued as topics that promote SD? Which goals are presented more frequently?

The purpose of this study is to investigate appropriate topics for future teachers to teach in classes that would cover the benefits and knowledge of the 17 SDGs. Additionally, the study will also investigate the relation of ELT and SDGs. Although ESD currently holds no prominent position in ELL and ELT, as practicing general English, reading, composing, listening, and speaking are prominent, this study examines the future teachers' knowledge gaps in SD and suggestions to fill these gaps. We will show the importance of SDGs being instilled at HEIs, specifically at the Faculty of Education. These students are future teachers, and they must have some knowledge about global issues and SDGs to pass on to their students.

\section{Methods}

\section{Research Design}

The study was conducted at a public HEl, the University of Mitrovica in Kosovo, with the students from the Faculty of Education. The procedure followed the methodology of Balčiūnaitienè and Teresevičienè (2018) conducted for sustainable development and ELT. 
Bekteshi, E., \& Xhaferi, B. (2020). Learning about Sustainable Development Goals through English Language Teaching.

However, it was modified and adapted to fulfill the study aims, i.e., to answer the previously mentioned questions dealing with the future teachers' general awareness about SD, specific SD Goals, and the ELT effect in SD learning.

\section{Participants and Instruments}

For the purpose of the study, the researchers conducted an online questionnaire that was distributed to the students of the $2 \mathrm{nd}$, 3rd, and 4th year of their studies at the Faculty of Education (future Kosovar teachers) in 2019/2020. The questionnaire, comprised of 12 questions regarding SD, SDGs, and ELT, was divided into three parts:

- The first group of questions dealt with the students' awareness about SD and SDGs.

- The second group dealt with the SDGs and the country's needs based on students' perceptions.

- The third group of questions dealt with the relation between SD, ELL, and ELT from the students' points of view.

Initially, in order to have more reliable data by considering different topics that were learned during the students' educational experience, the list of the UN's 17 SDGs was offered to the students.

The questionnaire went online in mid-October 2019 and it was active until the end of February 2020. During this time, a group of 89 female students $(n=89)$ responded to the questionnaire survey. These respondents were students who already had 10 years of English prior to continuing Bachelor studies in our public HEls. In addition, for the purpose of better understanding the study questions, the questionnaire was bilingual: English and the students' native language, Albanian.

\section{Data Collection and Data Analysis}

The results were collected and analyzed using SPSS statistical methods for each group of questions. Data analysis comprised of three and/or five SDGs based on the questionnaire requests, then compared them with each other. The top three and/or five goals were taken into consideration, as they were the chosen goals by most of the future teachers. It followed the methodology of Balčiūnaitienè and Teresevičienè (2018) in finding out students' knowledge about SD, SDGs, and their correlations with ELT. Based on our study's statistical analysis, discussions of findings were linearly incorporated within the study questions, synthesized, and summarized. 
Bekteshi, E., \& Xhaferi, B. (2020). Learning about Sustainable Development Goals through English Language Teaching.

Although the participants' numbers do not represent the overall number of students in the Faculty of Education, the results are a great help in analyzing the situation of the ESD at a HEI in Kosovo, and the ELT role concerning the SD concept.

\section{Results}

The collection of data took place in March 2020, and the findings for each question posed are as follows:

- Research Question 1: To what extent are the students in tertiary education (at a public $\mathrm{HEl}$ in Kosovo) aware of SD and its goals?

Starting with the first question of the questionnaire, "Have you heard of Sustainable Development (SD)? What does Sustainable stand for?" the results reveal that $60.7 \%$ of students have some understanding of the notion of SD, although SD is a new idea in Kosovo (Beka \& Ciani, 2015). However, the other group (39.3\%) reveals that there is also a large number of students who do not understand the SD concept. The responses that the students do not understand the SD concept urge the HEIs, especially the Faculty of Education, to take immediate steps to promote SD among the future teachers. The responses of these questions unveil straightforward evidence about the first study question regarding the future teachers' awareness of the SD concept, which is shown in Table 1.

Table 1.

Awareness about SD

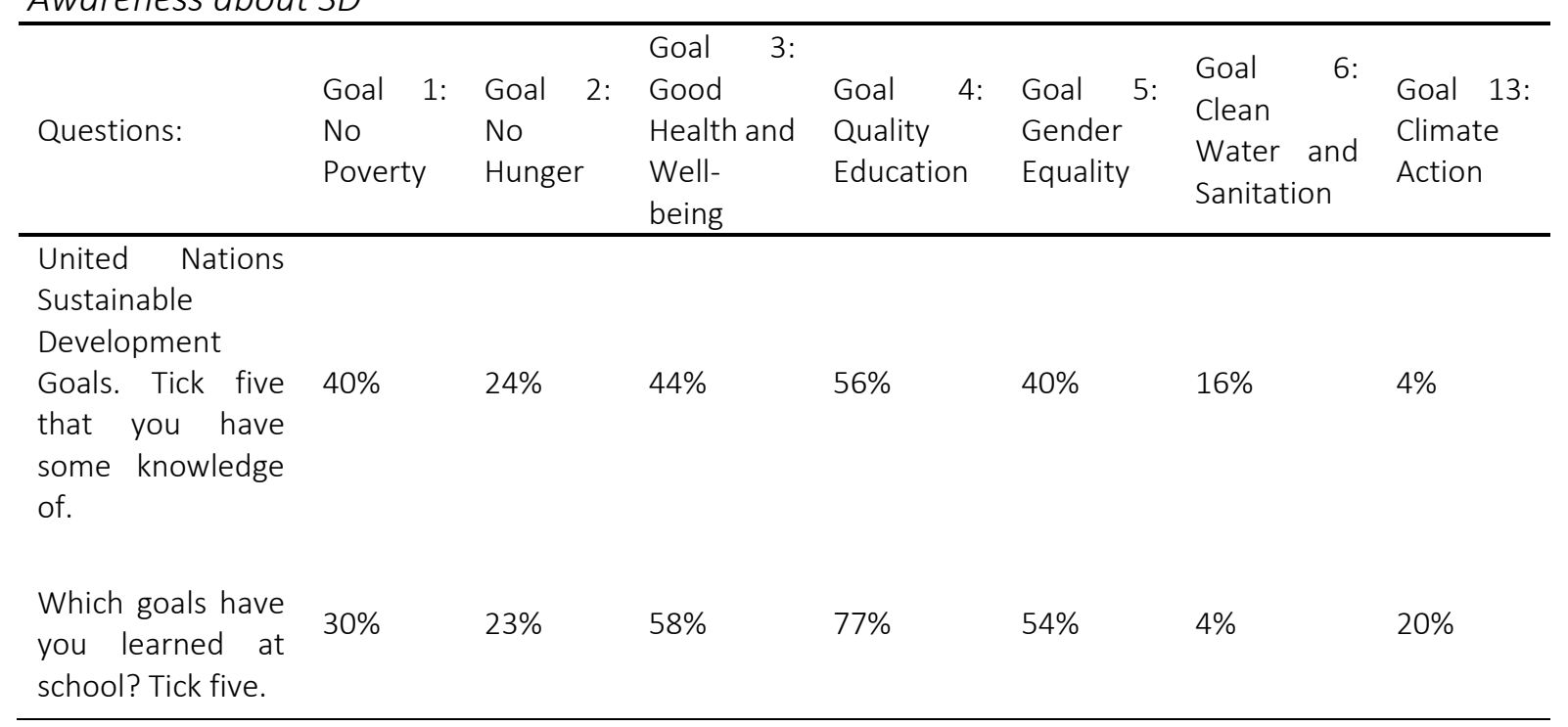


Additionally, when offering the students the list of the SDGs, the results (Table 1 ) reveal that out of the 17 SD goals, the best known goal is Goal 4: Quality Education (56\%), which is introduced by different topics, i.e., learned at school (77\%), followed by Goal 3: Good Health and Well-being (44\%). The topics dealing with Goal 3 make the students understand this goal, and it is also discussed at school (58\%) through different topics. As seen from the results, the students have knowledge of the SDGs when they have learned about them at school. Furthermore, Goal 4: Quality Education, Goal 3: Good Health and Well-being, and Goal 5: Gender Equality are the leading goals about which the students from the Faculty of Education have some knowledge.

- Research Question 2: Which SDGs do students/future teachers consider to be important goals that they need to know?

The template of the responses does not lead to variations in reporting when comparing the students' responses about the goals of which they have some understanding, as well as those goals that students have mostly learned about at school (Table 1). In Table 2, we see the preferred goals compared to the goals they think they will need in life. The high percentage of the responses for the same goals confirm that the goals learned are needed in the course of a lifetime. The results shown in Table 2 respond to the second study question. As reviewed, Goal 4 is considered as the most needed, whereas Goal 3 as the most important to know.

Table 2.

The need to learn about SD

\begin{tabular}{|c|c|c|c|c|c|c|c|}
\hline Questions: & $\begin{array}{l}\text { Goal 1: } \\
\text { No } \\
\text { Poverty }\end{array}$ & $\begin{array}{l}\text { Goal 2: } \\
\text { No } \\
\text { Hunger }\end{array}$ & $\begin{array}{l}\text { Goal 3: } \\
\text { Good } \\
\text { Health } \\
\text { and Well- } \\
\text { being }\end{array}$ & $\begin{array}{l}\text { Goal 4: } \\
\text { Quality } \\
\text { Education }\end{array}$ & $\begin{array}{l}\text { Goal 5: } \\
\text { Gender } \\
\text { Equality }\end{array}$ & $\begin{array}{l}\text { Goal 8: } \\
\text { Decent } \\
\text { Work and } \\
\text { Economics }\end{array}$ & $\begin{array}{l}\text { Goal 17: } \\
\text { Partnership to } \\
\text { Achieve the } \\
\text { Goal }\end{array}$ \\
\hline $\begin{array}{l}\text { Which of } \\
\text { these goals } \\
\text { do you think } \\
\text { you will need } \\
\text { in life? }\end{array}$ & $16 \%$ & $20 \%$ & $52 \%$ & $56 \%$ & $28 \%$ & $24 \%$ & $12 \%$ \\
\hline $\begin{array}{l}\text { Which of the } \\
\text { goals do you } \\
\text { think each } \\
\text { person } \\
\text { should know } \\
\text { about? Tick } \\
\text { three. }\end{array}$ & $32 \%$ & $28 \%$ & $56 \%$ & $48 \%$ & $16 \%$ & $24 \%$ & $20 \%$ \\
\hline
\end{tabular}


Bekteshi, E., \& Xhaferi, B. (2020). Learning about Sustainable Development Goals through English Language Teaching.

- Research Question 3: Which goals do the students consider as the eminent goals in the country? Which goals do the students consider less applicable in their country?

The students' awareness about the country's needs for SD are shown in Table 3. The results reveal again that the most important goal is Goal 4: Quality Education, as 68\% of the students' responses show that Goal 4 is the most important goal within the country. As such, these responses (Table 3 and Table 4) answer the third study question.

Table 3.

The country's needs based on SD

\begin{tabular}{|c|c|c|c|c|c|c|c|c|}
\hline Questions: & $\begin{array}{l}\text { Goal 1: } \\
\text { No } \\
\text { Poverty }\end{array}$ & $\begin{array}{l}\text { Goal 2: } \\
\text { No } \\
\text { Hunger }\end{array}$ & $\begin{array}{l}\text { Goal } \\
3: \\
\text { Good } \\
\text { Health } \\
\text { and } \\
\text { Well- } \\
\text { being }\end{array}$ & $\begin{array}{l}\text { Goal 4: } \\
\text { Quality } \\
\text { Education }\end{array}$ & $\begin{array}{l}\text { Goal 5: } \\
\text { Gender } \\
\text { Equality }\end{array}$ & $\begin{array}{l}\text { Goal } \\
\text { Industry, } \\
\text { Innovation } \\
\text { and } \\
\text { Infrastructure }\end{array}$ & $\begin{array}{l}\text { Goal 16: } \\
\text { Peace and } \\
\text { Justice Strong } \\
\text { Institutions }\end{array}$ & $\begin{array}{l}\text { Goal 17: } \\
\text { Partnership } \\
\text { to Achieve } \\
\text { the Goal }\end{array}$ \\
\hline $\begin{array}{l}\text { These five } \\
\text { goals are } \\
\text { important } \\
\text { for my } \\
\text { country. }\end{array}$ & $40 \%$ & $36 \%$ & $44 \%$ & $68 \%$ & $44 \%$ & $36 \%$ & $32 \%$ & $40 \%$ \\
\hline
\end{tabular}

Although not experts in the field of teaching, but still future teachers, their point of view about the application of the SDGs in Kosovo is shown in Table 4. The results reveal that decent work and economics (Goal 8) is the least applicable goal (52\%). Comparing Table 3 and Table 4, both tables show that Goal 5: Gender Equality is an important goal for Kosovo, yet it is not applied.

\section{Table 4.}

Goals not applicable in Kosovo

\begin{tabular}{|c|c|c|c|c|c|c|c|c|}
\hline Questions & $\begin{array}{l}\text { Goal 5: } \\
\text { Gender } \\
\text { Equality }\end{array}$ & $\begin{array}{l}\text { Goal 6: } \\
\text { Clean } \\
\text { Water } \\
\text { and } \\
\text { Sanitation }\end{array}$ & $\begin{array}{l}\text { Goal 7: } \\
\text { Affordable } \\
\text { and Clean } \\
\text { Energy }\end{array}$ & $\begin{array}{l}\text { Goal 8: } \\
\text { Decent } \\
\text { Work and } \\
\text { Economics }\end{array}$ & $\begin{array}{l}\text { Goal 9: } \\
\text { Industry, } \\
\text { Innovation } \\
\text { and } \\
\text { Infrastructure }\end{array}$ & $\begin{array}{l}\text { Goal 13: } \\
\text { Climate } \\
\text { Action }\end{array}$ & $\begin{array}{l}\text { Goal 16: } \\
\text { Peace and } \\
\text { Justice } \\
\text { Strong } \\
\text { Institutions }\end{array}$ & $\begin{array}{l}\text { Goal 17: } \\
\text { Partnership } \\
\text { to Achieve } \\
\text { the Goal }\end{array}$ \\
\hline $\begin{array}{l}\text { These five } \\
\text { goals are } \\
\text { not } \\
\text { applicable } \\
\text { in my } \\
\text { country }\end{array}$ & $40 \%$ & $32 \%$ & $44 \%$ & $52 \%$ & $28 \%$ & $36 \%$ & $28 \%$ & $28 \%$ \\
\hline
\end{tabular}

The findings reveal that SD teaching and learning requires and urges multidimensional, comprehensive forms and new teaching topics in which students can build their knowledge. 
That is, introduction of innovative topics requires innovative understanding based on $21^{\text {st }}$ century needs and, as such, we may add that this is precisely what the SDGs are about: the understanding of GloCal $21^{\text {st }}$ century needs (Bekteshi, 2017). That is, learning about the SDGs is learning about discoveries, as pointed out by Richards and Rodgers (1986), that learning is facilitated when the learner discovers or creates by problem solving and by involving the material to be learned.

- Research Question 4: To what extent are topics presented in EL classes valued as topics that promote SD? Which goals are presented more frequently?

Although SDG topics encompass important issues in education, the students' responses reveal that there is a problem in linking ELT and SDGs. Of the 17 goals, six goals were mostly chosen as goals that relate ELT and SDGs, as presented in Table 5. As shown, ELT mostly introduces topics dealing with Goal 4 and Goal 3.

\section{Table 5.}

The relation of SD and ELT

\begin{tabular}{|c|c|c|c|c|c|c|}
\hline Questions: & $\begin{array}{l}\text { Goal 2: } \\
\text { No } \\
\text { Hunger }\end{array}$ & $\begin{array}{l}\text { Goal 3: } \\
\text { Good } \\
\text { Health } \\
\text { and } \\
\text { Well- } \\
\text { being } \\
\end{array}$ & $\begin{array}{l}\text { Goal 4: } \\
\text { Quality } \\
\text { Education }\end{array}$ & $\begin{array}{l}\text { Goal 5: } \\
\text { Gender } \\
\text { Equality }\end{array}$ & $\begin{array}{l}\text { Goal 8: } \\
\text { Decent } \\
\text { Work and } \\
\text { Economics }\end{array}$ & $\begin{array}{l}\text { Goal 17: } \\
\text { Partnership to Achieve } \\
\text { the Goal }\end{array}$ \\
\hline $\begin{array}{l}\text { These three } \\
\text { goals are } \\
\text { learned in } \\
\text { English classes. }\end{array}$ & $20 \%$ & $40 \%$ & $48 \%$ & $36 \%$ & $28 \%$ & $24 \%$ \\
\hline $\begin{array}{l}\text { These three } \\
\text { goals can be } \\
\text { easily learned } \\
\text { through English } \\
\text { Language } \\
\text { classes }\end{array}$ & $20 \%$ & $28 \%$ & $48 \%$ & $48 \%$ & $24 \%$ & $20 \%$ \\
\hline $\begin{array}{l}\text { These five goals } \\
\text { should be } \\
\text { definitively } \\
\text { learned in } \\
\text { English classes. }\end{array}$ & $24 \%$ & $44 \%$ & $56 \%$ & $44 \%$ & $36 \%$ & $20 \%$ \\
\hline
\end{tabular}

Goal 4: Quality Education is the most preferred goal when discussing the relation of SD and ELT. Quality Education is being discussed in ELT classes (48\%), and it is the goal that can be easily learned (48\%) and should be learned (56\%). The second most preferred goal in ELT is Goal 5: 
Bekteshi, E., \& Xhaferi, B. (2020). Learning about Sustainable Development Goals through English Language Teaching.

Gender Equality. The students' responses reveal that topics about gender equality can be easily learned in ELT classes (48\%), and the results advise the teachers to teach about gender equality in ELT (44\%). Additionally, on the question about whether different topics about SD presented in ELT classes will enhance communicative skills, 92\% of the students agree that these kinds of topics can help in communicative skills and can increase the students' interest in learning (96\%). Accordingly, it is seen that the results support the idea of innovative education that can be achieved via communication about SDGs as $21^{\text {st }}$-century knowledge. Application of skills, attitudes, and competences that students need to develop (Balčiūnaitienè \& Teresevičienė, 2018; Kioupi \& Voulvoulis, 2019) are all connected when learning about SDGs.

\section{Discussion}

The results of this study demonstrate significant information about the Kosovar students' knowledge of SD, SDGs, and the relation of English Language classes and SD. Most of the future teachers have some understanding of SD; however, there is still a large number of them (39.3\%) who do not have any knowledge of SD.

Students in tertiary education in Kosovo (future teachers) consider Goal 4: Quality Education, Goal 3: Good Health and Well-being, and Goal 5: Gender Equality as the most important goals that they need to know. If we summarize all the SDG goals and student responses, Goal 4 is the most prominent goal, which was pointed out by Beka and Ciani (2015), Kioupi and Voulvoulis (2019), and Leicht, Heiss, and Byun (2018). Based on the study results, the same goals are considered the most important goals from a global viewpoint as well as in a national/Kosovar aspect; students consider Goal 4: Quality Education as the leading, most important goal in Kosovo. Indeed, the third most eminent goals are Goal 1: No Poverty and Goal 17: Partnership to Achieve the Goal. This confirms the students' interest in goals related to "P-People." On the other hand, based on students' opinions, Goal 8: Decent Work and Economics is considered the least applicable goal in Kosovo, followed by Goal 7: Affordable and Clean Energy, which shows a lack of interest in the other two "Ps," Profit and Planet. Surprisingly, goals regarding "P-Planet" are not mentioned by the students, neither as the needed goals to be learned nor applied, although initially SD at the HEI in Kosovo was presented with topics in the field of agriculture or environment (Beka \& Ciani, 2015).

Regarding the third group of responses, a variety of interpretations can be observed in the data about students' knowledge about the SD goals and the connections with ELT. The data proves that there are various topics in English classes that promote SDG learning, especially in Goal 3, Goal 4, and Goal 5. As seen from the results, the students' needs and wishes to learn about SD via English can be (un)limited and (un)predictable. Based on future Kosovar teachers' viewpoints, the results reveal facts about the relation of ELT and SDGs, especially how and why English and SD are linked. There is a global reference for SD topics that have a valid point toward the $21^{\text {st }}$ century and the " 3 Ps": People, Planet, and Profit (Gil-Doménech \& Berbegal- 
Bekteshi, E., \& Xhaferi, B. (2020). Learning about Sustainable Development Goals through English Language Teaching.

Mirabent, 2018), and the Kosovar students, future teachers, consider English learning as a good opportunity to pursue the SD goals and their usability in an intercultural environment, which is also pointed out by Lithuanian students in Balčiūnaitienè and Teresevičienè's (2018) study. The results reveal that ESD through ELT is an opportunity to expose intellectual aspects of future teachers to learn about the SDGs. Additionally, the results also reveal that teaching about the SDGs in English classes allows for full-fledged socialization in GloCal (global and local) learning for better life-planning, consequently allowing them to make spontaneous brilliant contributions to learning about People and Profit, leading to the appeal for more commitment to the "3 Ps" in a GloCal aspect. In particular, Goal 4: Quality Education, Goal 3: Good Health and Well-being, Goal 5: Gender Equality, Goal 2: No Hunger, Goal 8: Decent Work and Economics, and Goal 17: Partnership to Achieve the Goal are the leading goals mentioned in English classes.

These results for learning SDGs and their roles among the future teachers confirm that there is a significant positive effect in global and local perspectives. However, out of 17 SD goals, Kosovar students tackle only a few. And these goals are all related to social aspects, whereas goals related to "P-Planet" dealing with water sanitation, climate change, energy, economic growth, infrastructure, and cities are hardly mentioned by the students. Due to the absence of the environmental goals, the study is partly in line with Pope and Patterson (2012), who claim that citizenship and environmental education help students develop the knowledge, skills, and attitudes for the future; in our case, it is the students' development when learning about SDGs via English language.

\section{Conclusion}

Kosovo has been enhancing education and introducing global issues and SDG topics at all levels of education. In response to the first research question, we may conclude that higher education students at a public Faculty of Education in Kosovo are knowledgeable about ESD and SDGs. Different topics dealing with these goals are being taught at all levels of education.

The conclusion for the second research question is that the students view Goal 3, Goal 4, and Goal 5 as the most important goals, followed by Goal 1 and Goal 2. Although these goals have already been presented in the students' previous education, these five are still considered as goals that need more attention. This leads to the conclusion of the third research question. That is, goals dealing with People are considered the most important global goals of the $21^{\text {st }}$ century by these future teachers. Similarly, these goals are viewed as nationally needed goals. Other goals regarding Profit are slightly tackled by the students, whereas goals regarding the Planet are not shown in students' responses. 
Bekteshi, E., \& Xhaferi, B. (2020). Learning about Sustainable Development Goals through English Language Teaching.

Based on the future teachers' awareness about SDGs, what they already know, what they think is important to know, and what they want to know about these issues depends on students' development and their awareness of the global issues and their social impact. As such, we may also conclude that the effectiveness of teaching about the SD issues in English classes to Higher Education (HE) students in Kosovo is in line with SD-specific topics, and it depends largely on the students' attitudes toward learning about specific topics. Additionally, these future teachers prefer more topics regarding People and Profit even in ELT classes. Therefore, we may also conclude that topics that future teachers prefer to focus upon are topics regarding People and Profit in their native/Albanian courses and in English language classes.

Since this study identifies challenges and opportunities for future ELT methodology to address the issues of ESD and ELT, the findings can be considered for drafting future ELT curricula. As such, the ELT Curricula at HEls should reflect a global view, and suggestions are as follows:

- $\quad$ Future teachers should be allowed to choose their own topics for the purpose of learning English and SDGs.

- $\quad$ ELT and teaching of SD and its overall process should be based on a variety of collaborative teaching techniques designed to help them grow intellectually.

- $\quad$ ELT and teaching of SD should be organized in a way that challenges the students (and the teachers), encourages them, and brings freshness and creativity in class via preferred topics.

- $\quad$ ELT and teaching of SD should emphasize the active role of students in the society and their contribution to the "3 Ps."

- $\quad$ ELT and teaching of SD should include collaborative learning and self-initiated learning about general global knowledge such as gender equality, economy, planet, society, and environment.

- $\quad$ ELT and teaching of SD should include problem-solving activities designed to discuss GloCal issues.

In this study, our aim was to discuss SDGs and English language learning through SD topics as an important social issue. We may conclude that the impact of ELT on sustainability is definitely based on the balance between what the students are being taught, what they want to be taught, and what they need to be taught (as seen in Table 5). It is important for teachers of English (new or experienced) to broaden the vision and design of sustainable education to discussion. EL teachers' empowerment and students' engagement with SD issues convey an exact definition of societal development through communication of specific fields, i.e., "wider society in exploring, developing and manifesting sustainability values will enable them to act as agents for change" (Bowden 2010, p. 21). It is the teachers' job to teach all these issues by taking step-by-step actions, starting from the involvement of new knowledge about SD, new 
Bekteshi, E., \& Xhaferi, B. (2020). Learning about Sustainable Development Goals through English Language Teaching.

professional knowledge, the involvement of new teaching material, and new teaching approaches appropriate for modern needs. Or, as pointed out by Balčiūnaitienè and Teresevičienè (2018), "embedding sustainable development content and innovative methods of teaching into foreign language (English) classes, pedagogues are encouraged to update their teaching strategies with innovative approach to SD" (p. 54).

Like any other study, this study suffered from some limitations. As pointed out, the number of students who participated in the study did not include all students of the Faculty of Education. A larger sample is needed to have more reliable data in order to increase the validity of the findings. However, the participants' ability to notice the gaps in SDG awareness and the appeal to learn different topics about SDGs shows a need for further investigation. The needed and specified SD goals should be taught in English classes in order to see the impact of learning about the SDGs. Since more time is needed, another well-designed survey that relates parallel learning to SDGs and English is planned for future investigation.

\section{References}

Amin, M. A., \& Greenwood, J. (2018). The UN sustainable development goals and teacher development for effective English teaching in Bangladesh: A gap that needs bridging. Journal of Teacher Education for Sustainability, 20(2), 118-138. Retrieved from https://files.eric.ed.gov/fulltext/EJ1218224.pdf

Bakalar, B. (2018). Book Review: Justice on both sides: Transforming education through restorative justice. American Journal of Qualitative Research, 2(2), 145-149.

Balčiūnaitienè, A., \& Teresevičienè, M. (2018). Challenges of foreign language teaching and sustainable development competence implementation in higher education. Vocational Training: Paper and Realities, 29(1). DOI: https://doi.org/10.2478/vtrr2018-0004.

Beka, A., \& Ciani, A. (2015). Promoting education for sustainable development at the University of Prishtina, Kosovo. In W. Leal Filho et al. (Eds.), Integrating sustainability thinking in science and engineering curricula: World sustainability series (pp. 139-151). DOI 10.1007/978-3-319-09474-8_11

Bekteshi, E. (2017a). Innovations in teaching - A comparative paper of foreign language education. South East European Journal of Sustainable Development (SEEJS), 1(1), 41 51. Retrieved from https://seejsd.unt.edu.mk/wp-content/uploads/2018/04/SEEJSDVol-1-2018-finale11309-1.pdf 
Bekteshi, E., \& Xhaferi, B. (2020). Learning about Sustainable Development Goals through English Language Teaching.

Bekteshi, E. (2017b). The 'four Cs' - Collaboration, communication, critical thinking and creativity at The Faculty of Arts (FLUP), University of Porto, Porto, Portugal. Journal of International Social Research, 10(50), 56-62. DOI:10.17719/jisr.2017.1638

Bowden, R. (2010). Teaching English for sustainability. Journal of NELTA, 15(1-2), 16-21. https://doi.org/10.3126/nelta.v15i1-2.4605

Gil-Doménech, D., \& Berbegal-Mirabent, J. (2018). People, planet, profit: Training sustainable entrepreneurs at the university level. In S. Dhiman \& J. Marques (Eds.), Handbook of engaged sustainability (pp. 1-22). https://doi.org/10.1007/978-3-319-53121-2_38-1

Inceli, O. (2015). The Perceptions of English Teachers to the SIOP ${ }^{\circledR}$ Model and Its Impact on Limited English Proficiency. Journal of Ethnic and Cultural Studies, 2(1), 15-28.

Kioupi, V., \& Voulvoulis, N. (2019). Education for sustainable development: A systemic framework for connecting the SDGs to educational outcomes. Sustainability, 11(21), 1-18. https://doi.org/10.3390/su11216104

Leicht, A., Heiss, J., \& Byun, W. J. (Eds.). (2018). Issues and trends in education for sustainable development. Paris: UNESCO.

Maley, A., \& Peachey, N. (2017). Integrating global issues in the creative English language classroom: With reference to the United Nations sustainable development goals. Retrieved from https://www.teachingenglish.org.uk/sites/teacheng/files/PUB_29200_Creativity_UN _SDG_v4S_WEB.pdf

Parker, J. (2019). Second language learning and cultural identity. Journal of Curriculum Studies Research, 1(1), 33-42. https://doi.org/10.46303/icsr.01.01.3

Pesanayi, V. T., \& Lupele, C. (2018). Accelerating sustainable solutions at the local level. In A. Leicht, J. Heiss, \& W. J. Byun (Eds.), Issues and trends in education for sustainable development (pp. 177-195). Paris: UNESCO. Retrieved from https://unesdoc.unesco.org/ark:/48223/pf0000261808

Pope, A., \& Patterson, T. (2012). Two sides of the megalopolis: Educating for sustainable citizenship. Journal of Social Education Research, 3(20). Retrieved from https://jsser.org/index.php/jsser/article/view/138 
Bekteshi, E., \& Xhaferi, B. (2020). Learning about Sustainable Development Goals through English Language Teaching.

Qablan, A. (2018). Building capacities of educators and trainers. In A. Leicht, J. Heiss, \& W. J. Byun (Eds.), Issues and trends in education for sustainable development (pp. 133-157). Paris: UNESCO.

Richards, J., \& Rodgers, T. (1986). Approaches and methods in language teaching. Cambridge: Cambridge University Press.

Rieckmann, M. (2018). Learning to transform the world: Key competencies in education for sustainable development. In A. Leicht, J. Heiss, \& W. J. Byun (Eds.), Issues and trends in education for sustainable development (pp. 39-59). Paris: UNESCO.

Rogers, K., \& Hudson, B. (2011). The triple bottom line: The synergies of transformative perceptions and practices for sustainability. Retrieved from https://www.researchgate.net/publication/283710434_The_Triple_Bottom_Line_Th e_Synergies_of_Transformative_Perceptions_and_Practices_for_Sustainability_with _Barclay_Hudson_OD_Practitioner_Fall_2011

Schreiber, J. R., \& Siege, H. (Eds.). (2016). Curriculum framework: Education for sustainable development (2nd ed.). Retrieved from https://www.globaleslernen.de/sites/default/files/files/linkelements/curriculum_framework_education_for_sustainable_development_barriere frei.pdf

Tarman, B., \& Dev, S. (Eds.). (2018). Editorial: Learning transformation through innovation and sustainability in educational practices. Research on Social Sciences and Technology, 3(1), i-ii. Retrieved from https://ressat.org/index.php/ressat/issue/view/50

UN. (2018). Introduction to the high level political forum for sustainable development: Major groups and other stakeholders. United Nations Department of Economic and Social Affairs. Retrieved from https://www.un.org/ecosoc/sites/www.un.org.ecosoc/files/files/en/2018doc/HLPF_1 01_PPT_en.pdf

UN SDG: Sustainable development goals. Retrieved from https://unstats.un.org/sdgs/

UNECE. (2009). Learning from each other: The UNECE strategy for education for sustainable development. Retrieved from https://www.unece.org/fileadmin/DAM/env/esd/01_Typo3site/LearningFromEachOt her.pdf 
Bekteshi, E., \& Xhaferi, B. (2020). Learning about Sustainable Development Goals through English Language Teaching.

UNESCO. (2017). Education for sustainable development goals: Learning goals. Retrieved from http://unesdoc.unesco.org/ images/0024/002474/247444e.pdf

Vural, H. (2019). The Relationship of Personality Traits with English Speaking Anxiety. Research in Educational Policy and Management, 1(1), 55-74. https://doi.org/10.46303/repam.01.01.5

Weeks, C. (2018). 4 reasons to teach the sustainable development goals. Global Education. Retrieved from https://www.participatelearning.com/blog/4-reasons-to-teach-thesustainable-development-goals/

Zygmunt, T. (2016). Language education for sustainable development. Discourse and Communication for Sustainable Education, 7(1), 112-124. DOI: 10.1515/dcse-20160008 